\title{
Metabolism of Amino Acids in Protein-Calorie-Deficient Rats
}

\author{
By I. G. McFARLANE* AND C. von HOLT $\dagger$ \\ Department of Biochemistry, University of the West Indies, Kingston, Jamaica
}

(Received 21 October 1968)

\begin{abstract}
The overall oxidative degradation of leucine and phenylalanine, measured in vivo in rats fed on a $2 \%$-casein diet for 8 weeks, is markedly decreased as compared with controls, whereas that of glutamate and alanine is apparently unaffected. The decrease in leucine degradation is due, at least in part, to a block before the formation of 3-methylbutyryl-CoA (isovaleryl-CoA) in the catabolic pathway. This phenomenon is accompanied by increased incorporation of $\left[{ }^{14} \mathrm{C}\right]$ leucine into liver proteins, decreased urinary excretion of leucine and increased urinary excretion of 4-methyl-2-oxopentanoate ( $\alpha$-oxoisocaproate) by protein-depleted animals. The results suggest the existence of adaptive mechanisms that function to conserve an indispensable carbon skeleton.
\end{abstract}

The metabolic changes occurring in mammals as a result of a decreased dietary protein intake are manifold and, in some respects, quite drastic (Munro \& Allison, 1964). In spite of this, animals can survive for some considerable time on proteindepleted or protein-free diets (Mendes \& Waterlow, 1958). This suggests the existence of mechanisms of adaptation.

Such adaptations are mediated, ultimately, by alterations in the specific activities of various enzymes, in particular those involved in nitrogen metabolism (Knox, Auerbach \& Lin, 1956; Platt, Heard \& Stewart, 1964). Changes are found in the activities of arginase and $\mathrm{D}$-amino acid oxidase (Knox et al. 1956), both of which decrease with decreasing protein intake and increase when dietary protein is given. The activities of glutamateoxaloacetate transaminase, glutamate-pyruvate transaminase, glutamate dehydrogenase (Schimke, $1962 a)$, tryptophan pyrrolase, serine dehydratase and threonine dehydratase (Pitot, Potter \& Morris, 1961) all decrease in the livers of animals fed on low-protein or protein-free diets. The urea-cycle enzymes show similar responses (Schimke, 1962b).

In the present study we tested whether the overall metabolism of some amino acids in vivo, measured by the respiratory carbon dioxide production from these amino acids, was affected in animals fed on low-protein diets. It seemed that protein deficiency might influence the catabolism of essential and non-essential amino acids in different

*Present address: Department of Nutrition, Sir John Atkins Laboratories, Queen Elizabeth College, London, W. 8.

†Present address: Department of Biochemistry, University of Cape Town, Cape Town, South Africa. ways. Therefore the degradation of alanine and glutamate, as representatives of non-essential amino acids, and that of leucine and phenylalanine, as typical examples of compounds with an indispensable carbon skeleton, were investigated.

\section{MATERIALS AND METHODS}

Materials. Amino acids and 3-methylbutyric acid (isovaleric acid) labelled with ${ }^{14} \mathrm{C}$ were obtained from The Radiochemical Centre (Amersham, Bucks.) or from Calbiochem (Los Angeles, Calif., U.S.A.). Sodium 4-methyl2-oxo[1-14C]pentanoate ( $\alpha$-oxoisocaproate) was prepared from $\mathrm{DL}-\left[1-{ }^{14} \mathrm{C}\right]$ leucine by a modification of the method of Meister (1952) by using L-amino acid oxidase.

Animals and diets. Female albino rats of the Wistar strain, obtained from the University of the West Indies Pre-Clinical Departments' Animal House, were used in all experiments. Until they were 4 months old (body wt. approx. 165g.) all animals were fed on Purina Lab Chow (27\% protein, $46 \%$ carbohydrate) ad libitum. At this age rats were randomly separated into two groups. One group was fed on a protein-deficient diet composed of $2 \%$ casein, $\mathbf{8 4 . 5} \%$ carbohydrate (corn starch $40 \%$, glucose $25 \%$, sucrose $19.5 \%$ ), $5 \%$ coconut oil, $0.5 \%$ cod liver oil and $4 \%$ each of a Vitamin Diet Fortification Mixture and U.S.P. XIV Salt Mixture obtained from Nutritional Biochemicals Corp. (Cleveland, Ohio, U.S.A.). The second group continued to receive the Purina Lab Chow and was used as a control. The calorie intakes of the two groups were estimated in terms of the body surface area by the method of Lee (1929). On this basis average intakes of 2700 and $2200 \mathrm{kcal} . /$ $\mathrm{m} .^{2}$ /day were obtained for control and depleted rats respectively. The term 'protein-depleted rat' refers to an animal that had been fed on the protein-deficient diet for 8 weeks.

Measurement of catabolism of metabolites in vivo. Catabolism of metabolites in vivo was measured by monitoring the ${ }^{14} \mathrm{CO}_{2}$ output, after intraperitoneal injection of the 
${ }^{14} \mathrm{C}$-labelled metabolite, by using a continuously recording ${ }^{14} \mathrm{CO}_{2}$ analyser described by Holt \& Schmidt (1961). In all cases the respiratory ${ }^{14} \mathrm{CO}_{2}$ was monitored for $3 \mathrm{hr}$. starting immediately after injection of the labelled compound. The standard dosage was $1.0 \mu \mathrm{c} / 100 \mathrm{~g}$. body wt., injected intraperitoneally as an aqueous solution containing approx. $10 \mu \mathrm{c} / \mathrm{ml}$. Experiments were done in the morning between 8.00 a.m. and 10.00 a.m. after the rats had been kept without food for $14 \mathrm{hr}$. The average body weights of depleted and control rats were $108 \mathrm{~g}$. (94-118g.) and $190 \mathrm{~g}$. (179-201 g.). Radioactive solutions were standardized by liquid-scintillation counting.

Measurement of radioactivity. Except for the measurements of respiratory ${ }^{14} \mathrm{CO}_{2}$, all determinations of radioactivity were conducted with a Packard Tri-Carb model 314E liquid-scintillation spectrometer. The following scintillator solutions were used: toluene scintillator, containing $0.3 \mathrm{~g}$. of 1,4-bis-(4-methyl-5-phenyloxazol-2-yl)benzene and $5.0 \mathrm{~g}$. of 2,5-diphenyloxazole in 11 . of toluene [with ethanol added (final concn. 20\%, $/ / \mathrm{v}$ ) when aqueous solutions were to be counted]; dioxan scintillator, containing $0 \cdot 3 \mathrm{~g}$. of 1,4-bis-(4-methyl-5-phenyloxazol-2-yl)benzene, $7 \mathrm{~g}$. of 2,5-diphenyloxazole and $100 \mathrm{~g}$. of naphthalene in 11. of dioxan; scintillator gel, containing $2.5 \%(w / v)$ powdered Thixcin in toluene scintillator (Horrocks, 1962). All results are expressed as disintegrations/min. by using suitable internal standards and relating the count rate (counts/min.) to a standard ${ }^{14} \mathrm{C}$ source (Packard Instrument Co., La Grange, Ill., U.S.A.).

Measurement of incorporation of $[1-14 \mathrm{C}]$ leucine into total liver proteins. At zero time each animal was given $2.0 \mu \mathrm{C}$ of DL-[1.14C]leucine (specific radioactivity $7 \cdot 25 \mathrm{mc} / \mathrm{m}-\mathrm{mole}$ )/ $100 \mathrm{~g}$. body wt. by intraperitoneal injection. Animals had not been previously deprived of food and feeding was continued ad libitum during the experiment. Three control and three depleted animals were killed by decapitation at each of three periods (1,6 and $24 \mathrm{hr}$.) after the injection. Livers were excised and weighed, and portions of each liver were homogenized to a final concentration of $20 \%(w / v)$ in 0.25 $\mathrm{M}$-sucrose, $\mathrm{pH} 7 \cdot 8$. Protein was prepared for measurement of radioactivity by treating $3.0 \mathrm{ml}$. of each homogenate with $3.0 \mathrm{ml}$. of $10 \%(\mathrm{w} / \mathrm{v})$ trichloroacetic acid. The mixture was centrifuged and the nucleic acids in the residue were extracted with $5.0 \mathrm{ml}$. of $5 \%(w / v)$ trichloroacetic acid at $90^{\circ}$ for $30 \mathrm{~min}$. The residue was washed with three $2.0 \mathrm{ml}$. lots of diethyl ether. Finally the residue was dried to a fine powder on a water bath at $70^{\circ}$ under continuous stirring. Portions of the powders (5-10mg.) were suspended in $10 \mathrm{ml}$. of scintillator gel and their radioactivities measured (see above).

Measurement of DNA content of liver. The DNA content of hot-trichloroacetic acid extracts of the liver homogenates was determined by reaction with diphenylamine by the method of Schneider (1957), with sperm DNA as a standard.

Measurement of urinary excretion of leucine and 4-methyl2-oxopentanoate. Dosages of $2 \cdot 0 \mu \mathrm{C}$ of $\mathrm{DL}-[1-14 \mathrm{C}]$ leucine $(7 \cdot 25 \mathrm{mo} / \mathrm{m}-\mathrm{mole}) / 100 \mathrm{~g}$. body wt. were administered to rats intraperitoneally at 8.00 a.m., and the animals placed in metabolism cages designed for collection of faeces-free urine. Animals had not been previously deprived of food and feeding was continued ad libitum during the experiment. The urine collected from each animal over a $24 \mathrm{hr}$. period was divided into two equal portions. The presence of labelled 4-methyl-2-oxopentanoate in one half was deter- mined by treatment of $5.0 \mathrm{ml}$. portions with $3.0 \mathrm{ml}$. of saturated $\mathrm{Ce}\left(\mathrm{SO}_{4}\right)_{2}$ solution in $4 \mathrm{~N}-\mathrm{H}_{2} \mathrm{SO}_{4}$ (Meister, 1952). The ${ }^{14} \mathrm{CO}_{2}$ produced during this treatment was trapped in Hyamine hydroxide and its radioactivity measured by counting in toluene scintillator. The other half was treated with a small amount of activated charcoal, filtered and passed over a column $(30 \mathrm{~mm} . \times 50 \mathrm{~mm}$.) containing approx. $10 \mathrm{ml}$. of Dowex 50 (X8; $\mathrm{H}^{+}$form; 100-200mesh). The column was washed with 10 vol. of water and then eluted with $2 \mathrm{~N}-\mathrm{NH}_{3}$. The eluate was made up to a known volume and the radioactivities of $1.0 \mathrm{ml}$. portions were measured in $10 \mathrm{ml}$. of dioxan scintillator. Thin-layer chromatography of portions of the eluate on plates coated with silica gel $G$, with water-acetic acid $(200: 1, \nabla / v)$ as the mobile phase, revealed that over $85 \%$ of the radioactivity in the eluate was associated with a single ninhydrin-positive spot that had the same $R_{F}$ value as leucine. The remaining $15 \%$ was spread on either side of this area and was not associated particularly with any other ninhydrin-positive spot.

\section{RESULTS}

Catabolism of DL-glutamate, DL-alanine, DL-leucine and L-phenylalanine by control and protein-depleted rats in vivo. Animals from each of the two groups were injected with DL-[2-14C]glutamic acid $(0.5 \mathrm{mc} /$ m-mole), $\mathrm{DL}\left[2 .{ }^{14} \mathrm{C}\right]$ alanine $(1.0 \mathrm{mc} / \mathrm{m}-\mathrm{mole})$, DL[2-14 C]leucine $(3.5 \mathrm{mc} / \mathrm{m}-\mathrm{mole})$ and $\mathrm{L}$-[U.14C]phenylalanine $(10.0 \mathrm{mc} / \mathrm{m}-\mathrm{mole})$ and the radioactivity incorporated into respiratory carbon dioxide was determined. Results are shown in
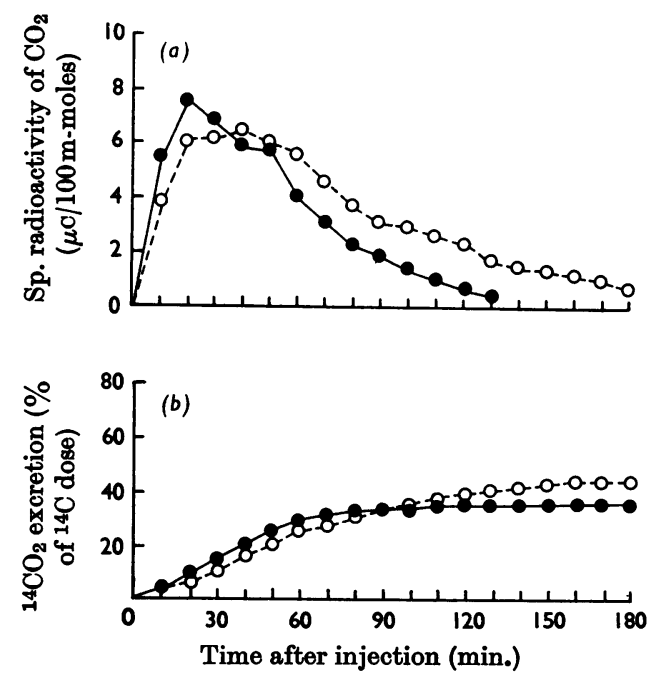

Fig. 1. Respiratory ${ }^{14} \mathrm{CO}_{2}$ measured after injection of DL-[2-14C]glutamic acid. (a) Changes in specific radioactivity of $\mathrm{CO}_{2}$ with time; (b) percentage of ${ }^{14} \mathrm{C}$ dose excreted. Each point represents the mean of observations on three animals. The average $\mathrm{CO}_{2}$ excretion was 8.93 and $11 \cdot 12 \mathrm{~m}-\mathrm{moles} / \mathrm{hr} . / 100 \mathrm{~g}$. body wt. for control $(\mathrm{O})$ and protein-depleted (०) rats respectively. 

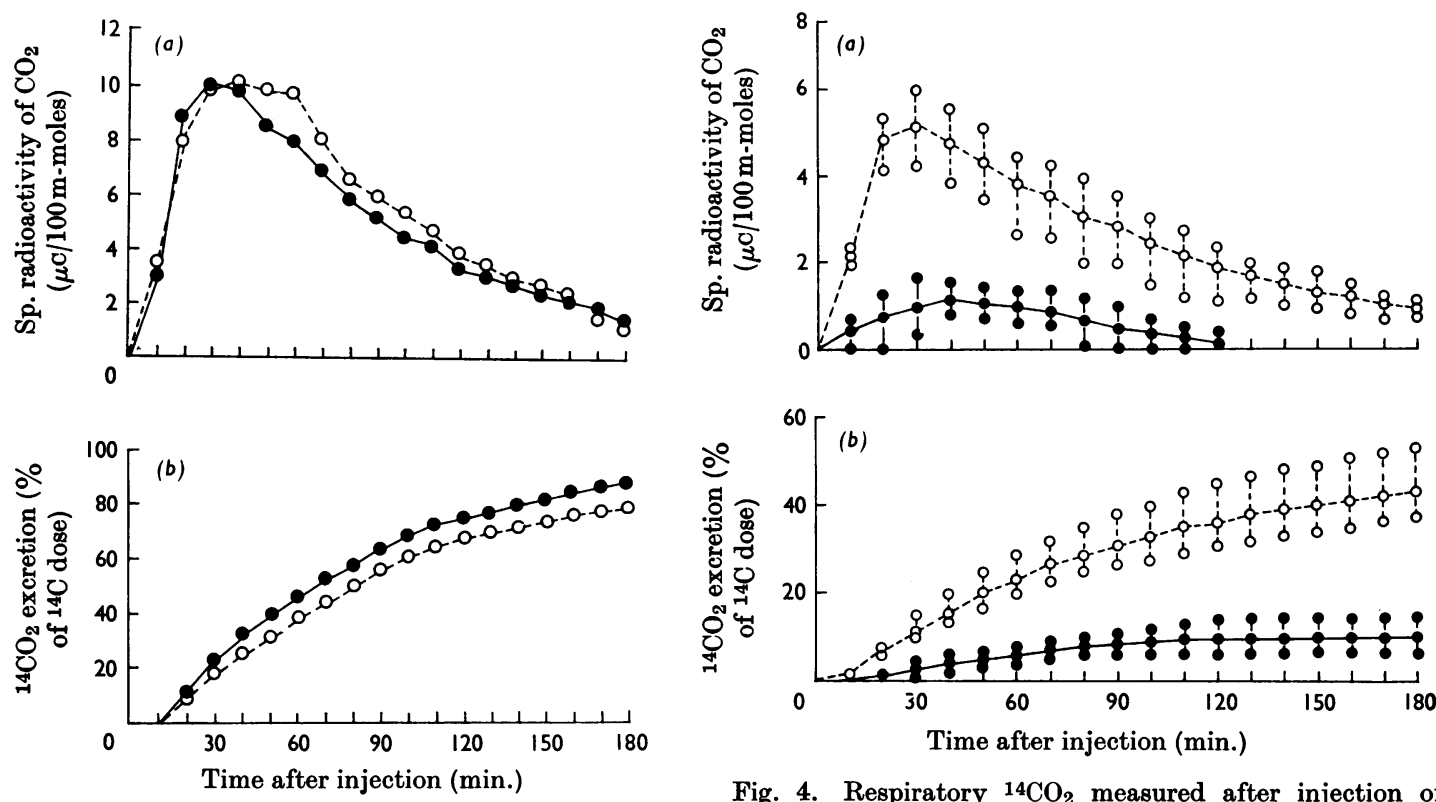

Fig. 2. Respiratory ${ }^{14} \mathrm{CO}_{2}$ measured after injection of DL-[2.14C $]$ alanine. (a) Changes in specific radioactivity of $\mathrm{CO}_{2}$ with time; $(b)$ percentage of ${ }^{14} \mathrm{C}$ dose excreted. Each point represents the mean of observations on three animals. The average $\mathrm{CO}_{2}$ excretion was 11.06 and $11.67 \mathrm{~m}-\mathrm{moles} / \mathrm{hr}$./ $100 \mathrm{~g}$. body wt. for control $(O)$ and protein-depleted (०) rats respectively.
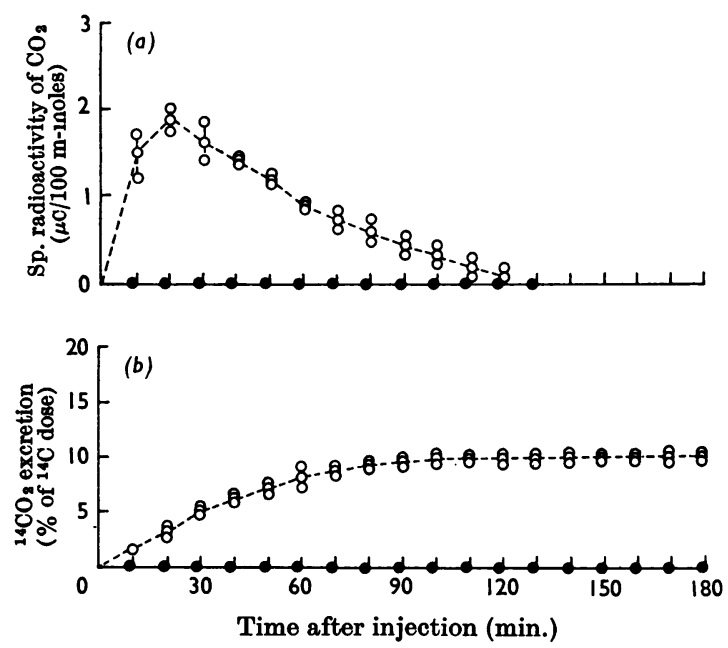

Fig. 3. Respiratory ${ }^{14} \mathrm{CO}_{2}$ measured after the injection o L-[U-14C]phenylalanine. The results of observations on three animals are shown. (a) Changes in specific radioactivity of $\mathrm{CO}_{2}$ with time; (b) percentage of ${ }^{14} \mathrm{C}$ dose excreted. The average $\mathrm{CO}_{2}$ excretion was 10.63 and $10 \cdot 71 \mathrm{~m}-\mathrm{moles} / \mathrm{hr} . / 100 \mathrm{~g}$. body wt. for control (O) and protein-depleted (๑) rats respectively.

Fig. 4. Respiratory ${ }^{14} \mathrm{CO}_{2}$ measured after injection of DL-[2-14C]leucine. The results of observations on three animals are shown. (a) Changes in specific radioactivity of ${ }^{14} \mathrm{CO}_{2}$ with time; $(b)$ percentage of ${ }^{14} \mathrm{C}$ dose excreted. The average $\mathrm{CO}_{2}$ excretion was 11.92 and $13.11 \mathrm{~m}-\mathrm{moles} / \mathrm{hr}$./ $100 \mathrm{~g}$. body wt. for control $(O)$ and protein-depleted $(0)$ rats respectively.

Figs. 1-4. In each case the changes in specific radioactivity of the respiratory carbon dioxide with time are given as well as the total excretion of the label. Variations in specific radioactivity of respiratory carbon dioxide show changes in the rate of catabolism of the amino acid more clearly than does a plot of the absolute amount of radioactivity excreted, whereas the latter gives information as to the total catabolism of the metabolite not revealed in the specific-radioactivity curves. A detailed analysis of the size and number of metabolic pools as well as of the effect of recycling of the label on the respiratory production of ${ }^{14} \mathrm{CO}_{2}$ from labelled precursors has been presented by Holt, Schmidt \& Feldmann (1961). The pool sizes for the amino acids under investigation are not known. The amounts of amino acids injected varied in the range $0 \cdot 1-2 \mu$ moles. The free amino acid content varies from tissue to tissue in the range $20-500 \mu$ moles $/ 100 \mathrm{~g}$. (Long, 1961). It was therefore considered that drastic changes of pool sizes were not induced by the injected amino acids.

Figs. 1 and 2 show that there is little difference between control and protein-depleted animals in the overall oxidative degradation of glutamate and alanine. The specific-radioactivity curves suggest a slightly higher degradation rate of glutamate in 


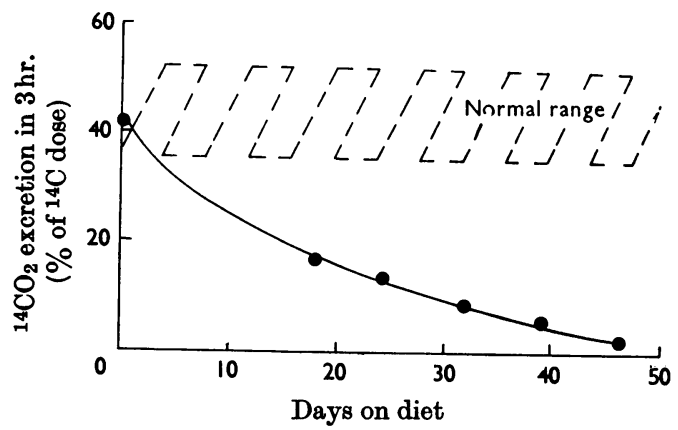

Fig. 5. Decrease in respiratory ${ }^{14} \mathrm{CO}_{2}$ from $\mathrm{DL}-\left[2-{ }^{14} \mathrm{C}\right]$ leucine observed in rats fed on a protein-calorie-deficient diet. The 'normal range' was obtained by screening five control animals over a period of 9 days. The values for proteindepleted (๑) rats were obtained from a group of five animals. Except for the 0-day and 46-day values, which were obtained from the same animal, each point represents a single observation on a different animal in the group.

the protein-depleted animals, but this is not considered significant.

As shown in Figs. 3 and 4, there are profound differences between control and protein-depleted animals in the degradation of phenylalanine and leucine. With the former no ${ }^{14} \mathrm{CO}_{2}$ was recovered at all from protein-depleted rats (Fig. 3). Since the total excretion of label as ${ }^{14} \mathrm{CO}_{2}$ from [U-14C]phenylalanine in control animals was only about $10 \%$ of the administered dose, it was recognized that a small amount of ${ }^{14} \mathrm{CO}_{2}$ may have been excreted by the protein-depleted animals but escaped detection. To investigate this possibility, a further two animals in this group were injected with a dosage of $2 \cdot 0 \mu \mathrm{c} / 100 \mathrm{~g}$. (i.e. a double dose). Under these conditions the ${ }^{14} \mathrm{CO}_{2}$ analyser would have been able to detect an excretion of less than $0.5 \%$ of the administered dose. However, the picture remained unchanged.

With regard to leucine, a total of 123 proteindepleted animals were screened during this work. In about $15 \%$ of animals a complete block in degradation was observed. For the remainder a small amount of respiratory ${ }^{14} \mathrm{CO}_{2}$ was detected. The results shown in Fig. 4 (obtained from three animals with parallel controls) are typical of the latter group. The mean respiratory ${ }^{14} \mathrm{CO}_{2}$ output of protein-depleted rats after injection of $\mathrm{DL}-\left[2-{ }^{-14} \mathrm{C}\right]$ leucine was about $25 \%$ that of control animals. This loss of ability develops gradually as the protein depletion becomes more pronounced (see Fig. 5).

Catabolism of 4-methyl-2-oxopentanoate and 3methylbutyrate by control and protein-depleted rats in vivo. Since the pathway of catabolism of leucine is much less complex than that of phenylalanine, leucine was chosen for further investigation. The
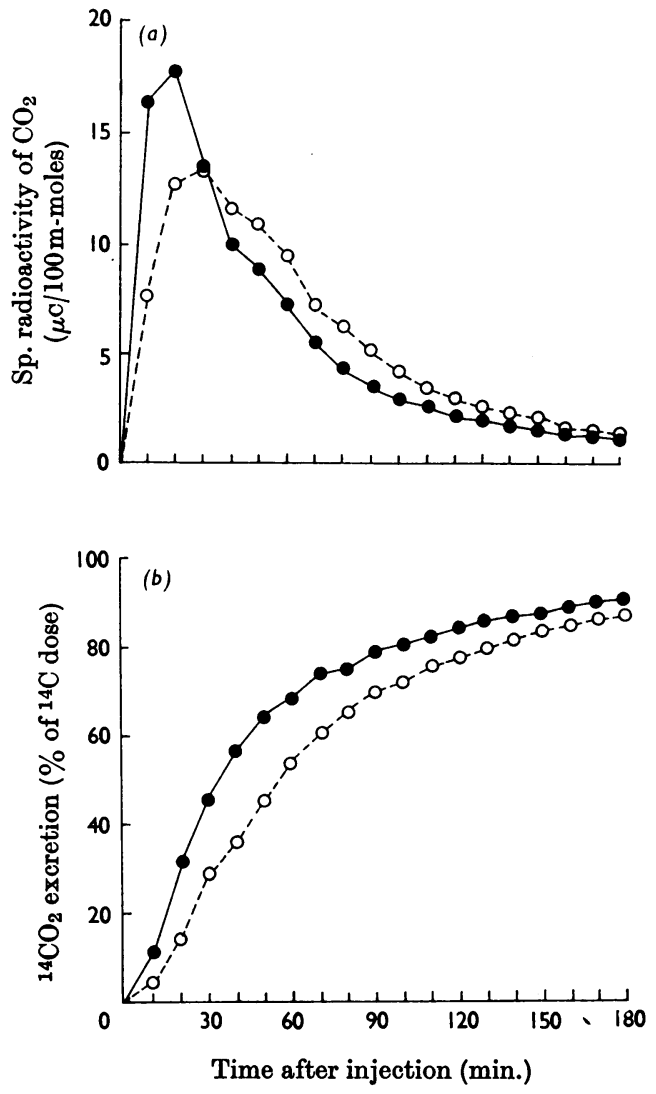

Fig. 6. Respiratory ${ }^{14} \mathrm{CO}_{2}$ measured after injection of sodium 3-methyl[1-14 C]butyrate. (a) Changes in specific radioactivity of ${ }^{14} \mathrm{CO}_{2}$ with time; (b) percentage of ${ }^{14} \mathrm{C}$ dose excreted. Each point represents the mean of observations on three animals. The average $\mathrm{CO}_{2}$ excretion was 12.47 and $12.98 \mathrm{~m}$-moles $/ \mathrm{hr} . / 100 \mathrm{~g}$. body wt. for control $(O)$ and protein-depleted (๑) rats respectively.

loss of the ability to catabolize leucine by proteindepleted rats could be due either to a general decrease in activity of all enzymes involved in the degradative pathway or to a block at a specific point in the pathway. Therefore the oxidation of the two metabolites immediately after leucine in the degradative pathway was investigated by monitoring the ${ }^{14} \mathrm{CO}_{2}$ production after injection of sodium 4-methyl-2-oxo[1-14 C]pentanoate $(0.05 \mathrm{mc} / \mathrm{m}$-mole $)$ and sodium 3-methyl[1-14 C]butyrate $(5 \cdot 80 \mathrm{mc} /$ m-mole).

As shown in Figs. 6 and 7, the degradation of 4-methyl-2-oxopentanoate in protein-depleted animals is approx. $60-70 \%$ less than in control rats, whereas that of 3-methylbutyrate is the same as in control rats except for a slightly higher degradation 
rate in the protein-depleted rats during the initial stages of the experiments. The pool sizes for 4-methyl-2-oxopentanoate and 3-methylbutyrate in the two groups of animals are not known. Therefore it is difficult to assess whether the in-
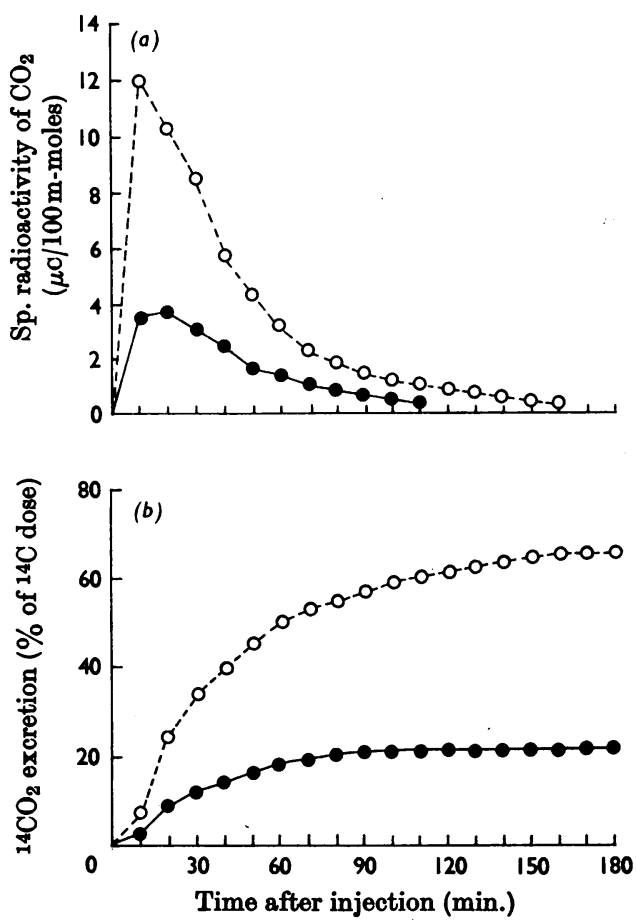

Fig. 7. Respiratory ${ }^{14} \mathrm{CO}_{2}$ measured after injection of sodium 4-methyl-2-oxo[1-14 $\mathrm{C}]$ pentanoate. (a) Changes in specific radioactivity of ${ }^{14} \mathrm{CO}_{2}$ with time; (b) percentage of ${ }^{14} \mathrm{C}$ dose excreted. Each point represents the mean of observations on three animals. The average $\mathrm{CO}_{2}$ excretion was $14 \cdot 66$ and $14 \cdot 67 \mathrm{~m}$-moles $/ \mathrm{hr} . / 100 \mathrm{~g}$. body wt. for control (O) and protein-depleted (०) rats respectively. jected amounts of the two acids can be considered as tracer amounts or not. In view of this the decrease in 4-methyl-2-oxopentanoate oxidation can only be taken as an indication that less of this compound is decarboxylated in protein-depleted animals. The magnitude of the decrease, however, suggests that protein depletion drastically affects either the influx into the pool (deamination) or the outflow (decarboxylation).

Investigation of two other metabolic fates of leucine. To investigate whether in addition to the decreased ability to oxidize leucine other metabolic fates of the amino acid were affected, the incorporation of the amino acid into hepatic protein and its excretion into urine were investigated. The results obtained with regard to incorporation into protein at various times after injection of labelled leucine are shown in Table 1. The amounts of the amino acid incorporated were related to DNA content of the liver, to fresh weight of tissue and to the body weight of the animal, and were also expressed as the percentage of the administered ${ }^{14} \mathrm{C}$ dose found in liver protein. The results show that, regardless of which parameter is used as a reference, the incorporation of labelled leucine into protein in the livers of protein-depleted animals is very much higher than for controls.

The excretion of both leucine and 4-methyl-2oxopentanoate into urine was determined. As shown in Table 2, protein-depleted animals exhibit a decreased urinary excretion of leucine and an increased excretion of 4-methyl-2-oxopentanoate as compared with control rats.

\section{DISCUSSION}

The results clearly indicate that the oxidative degradation of two essential amino acids (leucine and phenylalanine) is decreased in rats suffering from protein-calorie deficiency, whereas that of two non-essential amino acids (glutamate and

Table 1. Incorporation of $[1-14 \mathrm{C}]$ leucine into proteins of liver from control and protein-depleted rats at different time-intervals after its injection

The results are the means of the values obtained from three animals in each group at each time-interval. Values shown in parentheses denote the ranges.

Radioactivity incorporated (disintegrations/min.)

\begin{tabular}{|c|c|c|c|c|c|}
\hline $\begin{array}{c}\text { Rat } \\
\text { group }\end{array}$ & $\underset{\text { (hr.) }}{\text { Time }}$ & $\begin{array}{l}\text { (per mg. of } \\
\text { DNA) }\end{array}$ & $\begin{array}{l}\text { (per g. of } \\
\text { liver) }\end{array}$ & $\begin{array}{l}\text { (per } 100 \mathrm{~g} . \\
\text { body wt.) }\end{array}$ & $\begin{array}{c}\% \text { of }{ }^{14} \mathrm{C} \\
\text { dose retained }\end{array}$ \\
\hline $\begin{array}{l}\text { Control } \\
\text { Depleted }\end{array}$ & $\begin{array}{l}1 \\
1\end{array}$ & $\begin{array}{l}10820 \\
16900\end{array}$ & $\begin{array}{l}34000 \\
59800\end{array}$ & $\begin{array}{r}89000 \\
189000\end{array}$ & $\begin{array}{l}2.02(1 \cdot 75-2 \cdot 36) \\
4.29(3.81-4.54)\end{array}$ \\
\hline $\begin{array}{l}\text { Control } \\
\text { Depleted }\end{array}$ & $\begin{array}{l}6 \\
6\end{array}$ & $\begin{array}{l}23000 \\
41650\end{array}$ & $\begin{array}{r}63000 \\
127500\end{array}$ & $\begin{array}{l}157000 \\
431000\end{array}$ & $\begin{array}{l}3.57(3 \cdot 12-4 \cdot 11) \\
9 \cdot 79(8 \cdot 98-10 \cdot 48)\end{array}$ \\
\hline $\begin{array}{l}\text { Control } \\
\text { Depleted }\end{array}$ & $\begin{array}{l}24 \\
24\end{array}$ & $\begin{array}{l}18270 \\
36800\end{array}$ & $\begin{array}{r}48400 \\
103000\end{array}$ & $\begin{array}{l}132000 \\
365000\end{array}$ & $\begin{array}{l}3.00(2.83-3.25) \\
8.30(7.93-8.78)\end{array}$ \\
\hline
\end{tabular}




\section{Table 2. Urinary excretion of $[1-14 \mathrm{C}]$ leucine and 4-methyl-2-oxo[1-14C $]$ pentanoate by control and protein-depleted rats}

Each value is the mean of the results obtained from two animals, with the range shown as a deviation from the mean. Excretion was measured over a $24 \mathrm{hr}$. period.

\begin{tabular}{|c|c|c|c|c|}
\hline \multirow[b]{2}{*}{$\begin{array}{l}\text { Rat } \\
\text { group }\end{array}$} & \multicolumn{2}{|c|}{$[1-14 \mathrm{C}]$ Leucine excreted } & \multicolumn{2}{|c|}{ excreted } \\
\hline & $\begin{array}{c}\text { (disintegrations/min./ } \\
100 \mathrm{~g} \text {. body wt.) }\end{array}$ & $\begin{array}{l}\left(\% \text { of }{ }^{14} \mathrm{C}\right. \\
\text { dose) }\end{array}$ & $\begin{array}{c}\text { (disintegrations/min./ } \\
100 \mathrm{~g} \text {. body wt.) }\end{array}$ & $\begin{array}{l}\left(\% \text { of }{ }^{14} \mathrm{C}\right. \\
\text { dose })\end{array}$ \\
\hline Control & $477000 \pm 60000$ & $10 \cdot 8$ & $11021 \pm 1286$ & $0 \cdot 248$ \\
\hline Depleted & $307000 \pm 18000$ & $6 \cdot 9$ & $25250 \pm 2190$ & 0.569 \\
\hline
\end{tabular}

alanine) is not affected to any great extent (Figs. 1-4). The latter finding appears to conflict with reports that restriction of dietary protein intake results in decreased activities of glutamateoxaloacetate transaminase, glutamate-pyruvate transaminase (Awapara, 1953) and glutamate dehydrogenase (Schimke, 1962a) in mammalian tissues. However, other pathways make important contributions to the total amount of glutamate and alanine degraded in animal tissues. For example, decarboxylation of $\mathrm{L}$-glutamate to 4-aminobutyrate is a significant pathway of glutamate metabolism in mammalian brain (Meister, 1965). Thus it is conceivable that a block in transamination of glutamate and alanine may not significantly affect the overall carbon catabolism of these amino acids in vivo.

The decreased degradation of leucine is due to a metabolic block at a specific point in the pathway. This block occurs at some stage before the formation of 3-methylbutyryl-CoA. The results suggest that impairment of the decarboxylation of 4-methyl-2oxopentanoate is partly or wholly responsible for the block. Whether the transamination of $\mathrm{L}$-leucine or the oxidative deamination of $\mathbf{D}$-leucine (or both) is also affected cannot be deduced from the available evidence. However, it has been reported (Knox et al. 1956) that $\mathrm{D}$-amino acid oxidase activity is decreased in protein-depleted animals. Because the labelled leucine used in the present experiments was a racemate it is possible that a combined effect may be operating. On the other hand, the fact that there is an increase in the excretion of 4-methyl-2 oxopentanoate (Table 2) suggests that a block in decarboxylation is mainly responsible for the accumulation of this metabolite. An indication that a similar mechanism may operate with phenylalanine is suggested by a report by Krishnaswami (1964) that children suffering from kwashiorkor exhibit increased urinary excretion of phenylpyruvate.

The overall metabolic fate of leucine in proteindepleted rats is heavily biased in favour of conservation of the amino acid. During the first few hours after injection of labelled leucine, control rats excrete approx. $50 \%$ of the ${ }^{14} \mathrm{C}$ dose in respiratory carbon dioxide (Fig. 3). A further $11 \%$ is excreted in the urine as leucine and 4-methyl-2-oxopentanoate (Table 2). The remainder (less than $40 \%$ ) is retained in the body, presumably largely as a component of protein. With protein-depleted animals, however, less than $10 \%$ of the ${ }^{14} \mathrm{C}$ dose is excreted in either respiratory carbon dioxide or the urine during the same period. This means that over $90 \%$ of the labelled leucine is retained in the body, a fact that correlates very well with the observed two- to three-fold increase in incorporation of leucine into liver proteins (Table 1). The increased incorporation of labelled leucine into liver proteins of protein-depleted animals confirms previous observations (Solomon \& Tarver, 1952; Schrier \& Kazassis, 1960; Muramatsu, Sato \& Ashida, 1963). Similar results were also obtained by Waterlow \& Stephen (1966) for the incorporation of $\left[{ }^{14} \mathrm{C}\right]$ lysine. These authors have cautioned against the interpretation of differences in incorporation rate in terms of differences in rates of protein synthesis, because the speed of incorporation of an amino acid will depend on its specific radioactivity in the metabolic pool and how this changes with time. Nevertheless the combination of decreased oxidative degradation, increased incorporation into protein and diminished excretion of leucine in the urine cannot be explained by either decreased pool size or changes in specific radioactivity in the pool alone. It rather suggests the existence of adaptive mechanisms resulting in the conservation of the essential carbon skeleton of the amino acid. The accompanying paper (McFarlane \& Holt, 1969) presents evidence for such adaptions in protein-depleted animals.

We acknowledge the support received from the Medical Research Council (Grant no. G.964/108/T). This work has been presented as part of a Thesis submitted by I. G. McF. for the Ph.D. degree of the University of London in 1967.

\section{REFERENCES}

Awapara, J. (1953). J. biol. Chem. 200, 537.

Holt, C. von \& Schmidt, H. (1961). Biochem. Z. 334, 516. Holt, C. von, Schmidt, H. \& Feldmann, H. (1961). Biochem. Z. 334, 546. 
Horrocks, D. L. (1962). Packard Technical Bulletin, no. 2 (revised). La Grange, Ill.: Packard Instrument Co. Inc. Knox, W. E., Auerbach, J. H. \& Lin, E. C. C. (1956). Physiol. Rev. 36, 164.

Krishnaswami, P. R. (1964). Abstr. 6th int. Congr. Biochem., New York, vol. 5, p. 238.

Lee, M. O. (1929). Amer. J. Physiol. 89, 24.

Long, C. (1961). Biochemists' Handbook, pp. 739, 748, 847. London: E. and F. N. Spon Ltd.

McFarlane, J. G. \& Holt, C. von (1969). Biochem.J.111, 565.

Meister, A. (1952). J. biol. Chem. 197, 309.

Meister, A. (1965). Biochemistry of the Amino Acids, vol. 2, chapter 6. New York and London: Academic Press Inc.

Mendes, C. B. \& Waterlow, J. C. (1958). Brit.J. Nutr. $12,74$.

Munro, H. N. \& Allison, J. B. (Eds.) (1964). Mammalian Protein Metabolism, vols. 1 and 2. New York and London: Academic Press Inc.
Muramatsu, K., Sato, T. \& Ashida, K. (1963). J. Nutr. 83, 186.

Pitot, H. C., Potter, V. R. \& Morris, H. P. (1961). Cancer Res. 21, 1001.

Platt, B. S., Heard, C. R. C. \& Stewart, R. J. C. (1964). In Mammalian Protein Metabolism, vol. 2, chapter 21. Ed. by Munro, H. N. \& Allison, J. B. New York and London: Academic Press Inc.

Schimke, R. T. (1962a). J. biol. Chem. 237, 459.

Schimke, R. T. (1962b). J. biol. Chem. 237, 1921.

Schneider, W. C. (1957). In Methods in Enzymology, vol. 3, p. 680. Ed. by Colowick, S. P. \& Kaplan, N. O. New York: Academic Press Inc.

Schrier, K. \& Kazassis, C. (1960). Nature, Lond., 187, 1117. Solomon, G. \& Tarver, H. (1952). J. biol. Chem. 195, 447.

Waterlow, J. C. \& Stephen, J. M. L. (1966). Brit. J. Nutr. 20,461 . 